Jurnal ECOTIPE, Vol. 8, No.2, Oktober 2021, Hal. 112-119

p-ISSN 2355-5068, e-ISSN 2622-4852

Akreditasi Kemenristekdikti (SINTA 4), SK. No.10/E/KPT/2019

DOI: 10.33019/jurnalecotipe.v8i2.2538

\title{
Rancang Bangun Robot Penyaji Minuman Menggunakan ATMega 8535 dan Mini Water Pump
}

\author{
Edilla$^{1}$, Muhammad Anwardi Pulungan ${ }^{2}$, Amnur Akhyan $^{3}$ \\ Program Studi Teknik Mekatronika, Politeknik Caltex Riau ${ }^{1}$ \\ Program Studi Teknik Mekatronika, Politeknik Caltex Riau ${ }^{2}$ \\ Program Studi Teknik Mekatronika, Politeknik Caltex Riau ${ }^{3}$ \\ *edilla@ pcr.ac.id ${ }^{1}$, anwardi@alumni.pcr.ac.id ${ }^{2}$, akhyan@ pcr.ac.id $^{3}$
}

\begin{abstract}
The drinks serving robot is built to serves a drink or a drink mixture. This robot provides 8 types of basic drinks and 8 types of mixed drinks. In contrast to several previous studies, this study applied a mini water pump as a supplier of beverage ingredients and did not use the gravity method so that the composition of the ingredients would be more precise. Users choose the desired drink by pressing the keypad button then ATMega8535 will process user selection then activate stepper motors of $x$ and $y$ axes that carrying the glass. After glass on position of selected drink ingredients then stepper motors will stop, and next step microcontroller will activate mini pump to fill the drink ingredients to the glass. After all ingredients filled into glass then the stepper motors will bring the glass to stirring position. Then a single action cylinder will lower the mixer into the glass, the motor on the end of the cylinder will rotate the mixer so that the drink is mixed. From the testing that has been done, the robot can recognize drinks orders that have been made by users before and able to present the drink correctly with $100 \%$ success performance. The average time needed to serve drinks that only consist of one type of ingredientsis 33.28 seconds and for mixed drinks need 37.9 seconds. The robot is also able to do the stirring process for this type of mixed drink well with a performance of $100 \%$ success
\end{abstract}

Keywords: Drink Serving, Mixing, Robot

\section{INTISARI}

Rancang bangun robot penyaji minuman ini berfungsi untuk menyajikan satu jenis ataupun campuran beberapa minuman. Minuman yang dapat disediakan adalah 8 jenis bahan minuman dan 8 jenis campuran bahan minuman tersebut. Berbeda dengan beberapa penelitian sebelumnya pada penelitian ini mengaplikasikan mini water pump sebagai penyuplai bahan minuman dan tidak menggunakan metode gravitasi sehingga komposisi bahan akan lebih presisi. Cara kerja robot ini dimulai dari penekanan keypad sebagai input. Kemudian mikrokontroler ATMega 8535 mengaktifkan motor stepper 1 dan 2 . Setelah gelas berada tepat di bawah wadah bahan minuman yang telah dipilih maka mikrokontroler mengaktifkan mini water pump untuk memompa minuman dari wadah ke gelas. Jika yang dipilih adalah minuman campuran maka setelah semua bahan minuman dimasukkan selanjutnya motor stepper akan aktif kembali dan membawa gelas menuju ke tempat pengadukan (mixer). Ketika gelas tepat berada dibawah mixer maka silinder aksi tunggal yang membawa mixer turun hingga beberapa saat kemudian mixer akan aktif. Keunggulan robot ini adalah dapat bergerak ke bahan minuman dengan pergerakan $\mathrm{x}$ dan y serta dapat mengaduk minuman. Dari pengujian yang sudah dilakukan robot ini dapat mengenali pesanan minuman yang sudah dibuat pengguna sebelumnya dan mampu menyajikan minuman tersebut dengan benar dengan unjuk kerja keberhasilan sebesar 100\%. Rata-rata lamanya waktu yang dibutuhkan untuk menyajikan minuman yang hanya terdiri atas 1 jenis bahan saja adalah sebesar 33,28 detik dan untuk jenis minuman campuran 2 atau 3 bahan membutuhkan waktu rata-rata selama 37,9 detik. Robot juga mampu melakukan proses pengadukan untuk jenis minuman campuran dengan baik dengan unjuk kerja keberhasilan sebesar $100 \%$.

Kata kunci: Penyaji Minuman, Pencampuran, Robot

\section{PENDAHULUAN}

Di Era modern ini peran teknologi sangat mempengaruhi kehidupan manusia. Bermacam-macam penelitian yang dilakukan hanya untuk membuat teknologi baru yang lebih praktis dan canggih. Seperti halnya sebuah mesin ataupun robot yang sangat dibutuhkan oleh manusia untuk membantu pekerjaan 
Jurnal ECOTIPE, Vol. 8, No.2, Oktober 2021, Hal. 112-119

p-ISSN 2355-5068, e-ISSN 2622-4852

Akreditasi Kemenristekdikti (SINTA 4), SK. No.10/E/KPT/2019

DOI: 10.33019/jurnalecotipe.v8i2.2538

manusia mulai dari industri manufaktur, kesehatan, transportasi sampai pada eksplorasi laut dan luar angkasa [1]. Tak terkecuali dalam hal membuat minuman seperti rancang bangun robot penyaji minuman yang berfungsi untuk mencampur dan mengaduk minuman di sebuah cafe, hotel dan semacamnya [2][3]. Bahkan pada beberapa penelitian lain juga dikaji dampak sosial dan psikologis intaraksi robot penyaji minuman ini dengan manusia dan juga pada bidang hiburan dan hospitality [4][5][6][7].

Dengan rancang bangun robot bartender tersebut maka mereka tidak lagi membutuhkan tenaga kerja yang banyak tentu saja ini akan membuat keuntungan besar. Penelitian ini memiliki fokus pada rancang bangun robot bartender yang dikontrol dengan ATMega8535 dengan 2 buah motor stepper, 1 buah silinder aksi tunggal, 1 buah motor DC dan mini water pump sebagai aktuatornya. Keunggulan robot yang akan dibuat ini adalah dapat bergerak ke bahan minuman dengan pergerakan $\mathrm{x}$ dan $\mathrm{y}$ serta dapat mengaduk minuman yang telah tercampur. Pembersihan pada pengaduk dilakukan secara manual agar rasa minuman yang akan diaduk berikutnya tidak berubah.

Beberapa poin penting yang menjadi konsentrasi pada penelitian ini antara lain adalah: (1) mengatur pergerakan robot pada sumbu $\mathrm{x}$ dan y secara otomatis (2) mengatur sekuensial pergerakan robot terhadap komposisi bahan minuman yang sudah dipilih oleh pengguna (3) mekanisme pengaturan komposisi dan takaran untuk setiap bahan serta mekanisme pengadukan campuran minuman. Dengan penelitian ini maka diharapkan dapat dibuat sebuah robot penyaji minuman yang dapat menyediakan minuman ataupun campuran minuman secara otomatis.

\section{LANDASAN TEORI}

\section{A. Barobot}

Pada penelitian yang telah dilakukan sebelumnya dengan topik sejenis adalah produk Barobot. Barobot merupakan robot penyaji minuman yang dibuat oleh tim yang dipimpin oleh Konrad Krzysztop Klepacki dengan tujuan membantu pelayan cafe untuk menyajikan minuman. Barobot tersebut bekerja secara otomatis sesuai keinginan user. User memilih minuman melalui LCD touchscreen yang telah disediakan. Minuman pada Barobot ini disusun pada sumbu x sehingga Barobot ini hanya bergerak pada satu sumbu. Penuangan minuman pada Barobot ini menggunakan kran yang terlebih dahulu harus ditekan. Oleh karena itu pada pembuatannya, Barobot menggunakan sistem mekanik menggunakan motor servo sebagai alat untuk menekan kran tersebut.

Tampilan Barobot tersebut dapat dilihat pada Gambar1. Selain itu, pembuatan mekanik Barobot ini menggunakan acrylic sehingga tampilannya kelihatan lebih halus [8]. Sistem pergerakan pada Barobot menggunakan motor stepper yang di couple dengan pulley. Pulley yang berputar akan memutar belt yang telah terpasang pada dudukan gelas Barobot. Hasil minuman yang disajikan oleh Barobot adalah minuman campuran. Namun minuman campuran yang dihasilkan tidak diaduk terlebih dahulu.

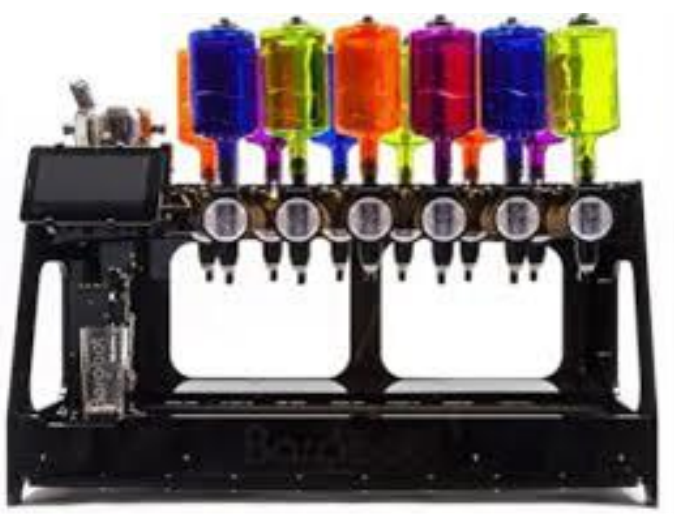

Gambar 1. Barobot

\section{B. The Inebriator}

Penelitian lain dengan topik yang sama adalah the Inebriator adalah robot bartender yang berfungsi untuk mencampurkan beberapa jenis minuman. Robot ini dibuat oleh Ian Cooper dan Jake Osborne dari Inggris dengan tujuan menggantikan atau membantu pelayan cafe dalam menyajikan minuman. User memilih minuman dengan tombol dan display untuk menunjukkan jenis minuman pada LCD 16x2.

Minuman pada the Inebriator ini disusun pada sumbu x sehingga robot ini hanya bergerak pada satu sumbu. Penuangan minuman pada the Inebriator ini menggunakan kran yang terlebih dahulu harus ditekan. Oleh karena itu pada pembuatannya, robot ini memiliki sistem mekanik menggunakan pneumatik sebagai alat untuk menekan keran tersebut [9]. Selain itu, pembuatan mekanik robot ini menggunakan besi hollow sehingga tampilannya kelihatan lebih simple, penampakan robot ini dapat dilihat pada Gambar 2.

Sistem pergerakan pada robot ini menggunakan motor stepper yang terletak sebagai dudukan gelas 
Jurnal ECOTIPE, Vol. 8, No.2, Oktober 2021, Hal. 112-119

p-ISSN 2355-5068, e-ISSN 2622-4852

Akreditasi Kemenristekdikti (SINTA 4), SK. No.10/E/KPT/2019

DOI: 10.33019/jurnalecotipe.v8i2.2538

sehingga motor stepper yang di couple dengan pulley bergerak pada jalur belt. Dengan kata lain, pada Barobot motor stepper diam dan menggerakkan dudukan gelas sedangkan pada Inebriator motor stepper yang bergerak dengan dudukan gelasnya sekaligus. Hasil minuman yang disajikan oleh robot ini adalah minuman campuran. Sama halnya dengan minuman campuran pada Barobot, pada robot ini minuman campuran juga tidak diaduk terlebih dahulu.

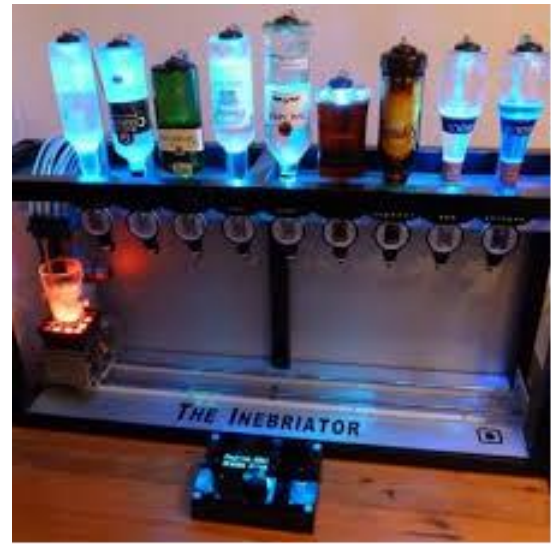

Gambar 2. The Inebriator

\section{Smart Bartender with Peristaltic Pumps}

Penelitian berikutnya adalah Smart Bartender yang dibuat oleh Vyacheslav Rybin dan kawankawan.produk yang mereka buat ini mengusung fitur penakaran cairan yang digunakan secara presisi dengan menggunakan pompa peristaltic. Produk yang dibuat ini memiliki kemampuan untuk membuat 6 sampai 32 jenis campuran minuman dengan takarannya masing-masing [10]. Tampilan produk ini dapat dilihat pada Gambar 3.

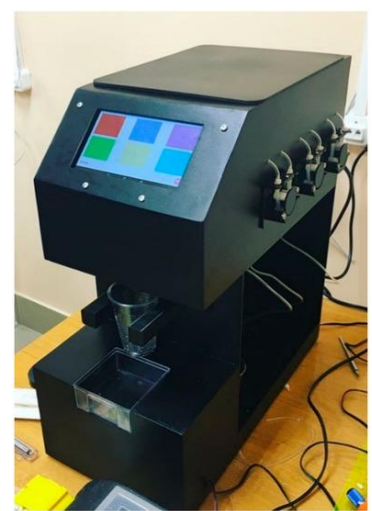

Gambar 3. Smart bartender with peristaltic pumps

\section{Motor Stepper}

Salah satu komponen selanjutnya adalah motor stepper. Aktuator ini menghasilkan gerakan mekanik berupa putaran yang dapat diatur sudurnya dengan memberikan masukan berupa pulsa elektronik. Berdasarkan lilitan stator, motor stepper terbagi menjadi dua tipe yaitu: unipolar dan bipolar. Rangkaian pengendali unipolar jauh lebih sederhana jika dibandingkan dengan rangkaian pengendali jenis bipolar.

Motor stepper biasanya memiliki spesifikasi khusus nilai phasa atau nilai derajat per step. Motor stepper juga memiliki kemampuan khusus torsi penahan dimana hal ini sangat berguna untuk aplikasi yang membutuhkan posisi awal dan akhir yang akurat. Secara umum kemampuan torsi dari sebuah motor stepper cenderung lebih rendah jika dibandingkan dengan motor DC yang lain, tapi tingkat kepresisian yang tinggi menjadi salah satu kelebihan motor stepper dibandingkan dengan yang lain [11].

\section{E. Mikrokontroler ATMega 8535}

Mikrokontroler AT Mega 8535 digunakan sebagai kendali utama pada penelitian ini. Chip mikrokontroller ini diproduksi oleh perusahaan Atmel. Secara umum chip mikrokontroller keluaran Atmel dapat dibagi menjadi 4 kelas yaitu:

1. ATtiny

2. ATMega

3. AT90Sxx

4. AT86RFx

Perbedaan antar kelas tersebut adalah kapasitas memori, peripheral, dan fungsinya sedangkan arsitektur dan instruksinya, hampir tidak ada perbedaan sama sekali. Dalam hal ini ATmega8535 dapat beroperasi pada kecepatan maksimal $16 \mathrm{MHz}$ serta memiliki 6 pilihan mode sleep untuk menghemat penggunaan daya listrik. [12] Konfigurasi pin dan fitur yang dimiliki oleh ATmega8535 dapat dilihat pada Gambar 4.

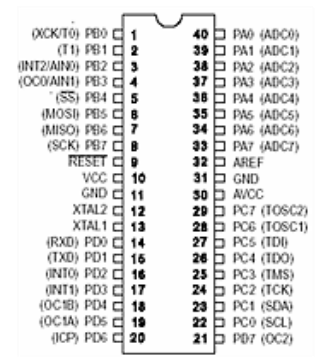

Gambar 4. Konfigurasi Pin ATmega8535 
Jurnal ECOTIPE, Vol. 8, No.2, Oktober 2021, Hal. 112-119

p-ISSN 2355-5068, e-ISSN 2622-4852

Akreditasi Kemenristekdikti (SINTA 4), SK. No.10/E/KPT/2019

DOI: 10.33019/jurnalecotipe.v8i2.2538

\section{METODE PENELITIAN}

Metode penelitian yang digunakan pada penelitian ini adalah dengan melakukan review literatur penelitian yang sudah dilakukan sebelumnya membandingkan dan mengevaluasi hasil pengujian dan kemudian hasil analisa ini akan menjadi dasar pemrograman alat dan kemudian data pergerakan yang dihasilkan dibandingkan pergerakan riil alat sesuai dengan urutan dan posisi mekanis alat. Penelitian ini mengambil posisi mengaplikasikan mini water pump sebagai suplai bahan minumannya dan tidak menggunakan motode gravitasi yang sering dipakai pada penelitian sejenis sebelumnya dengan tujuan menghasilkan komposisi bahan campuran yang stabil dan presisi tanpa dipengaruhi oleh volume bahan minuman. Pada penelitian ini juga menerapkan sistem pengaduk yang menjadi poin baru jika dibandingkan dengan penelitian dan produk yang sudah ada sebelumnya.

\section{A. Blok Diagram}

Secara umum alat ini memiliki keypad sebagai media input dan sarana interaksi user dan sistem alat. Mikrokontroler ATMega menjadi kontrol utama sistem yang mengatur pergerakan sumbu $\mathrm{x}, \mathrm{v}$, sekuensial pergerakan terakit pilihan minuman dan urutan proses. Perancangan alat secara umum dapat dilihat pada blok diagram yang ditampilkan pada Gambar 5.

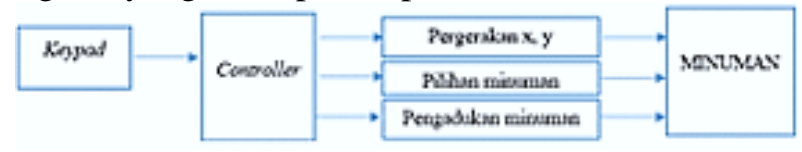

Gambar 5. Diagram blok sistem

\section{B. Desain Alat}

Pada alat ini didesain memiliki 8 tabung penyimpanan minuman. Adapun ke- 8 jenis minuman dasar tersebut adalah: (1)Teh; (2)Kuku Bima; (3) Fanta; (4)Sprite; (5)Air Gula; (6)Air Jeruk; (7)Susu Putih; (8)Susu Coklat. Dari kedelapan jenis minuman tersebut selanjutnya dibuat pilihan campuran minuman yang dapat diproses oleh alat yaitu: (1)Fanta + Susu Putih; (2)Kuku Bima+ Susu Putih; (3)Air Gula + Susu Putih; (4)Teh + Susu Putih; (5)Teh + Air Gula + Susu Putih; (6)Air Gula + Air Jeruk; (7)Air Gula + Air Jeruk + Susu Putih; (8)Air Gula + Susu Coklat.

Adapun desain alat ditampilkan pada Gambar 6.

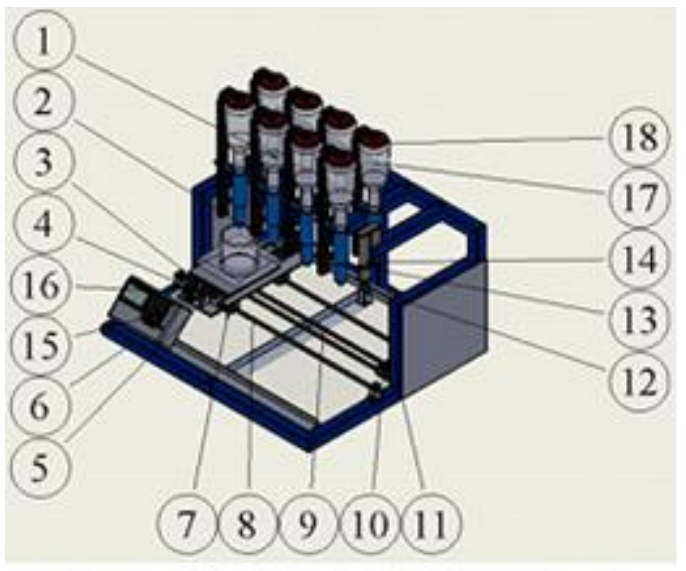

Gambar 6. Desain alat

Keterangan gambar :

1.Mini water pump

2.Gelas

3. Vertical bracket

4.Motor stepper 1

5.Linear actuator end

mount

6.Rangka

7.Linear bearing

8.Stainless shaft $8 \mathrm{~mm} 2$

9.Mxl timing belt $10 \mathrm{~mm}$

Adapun beberapa pengujian yang dilakukan pada penelitian ini di antaranya adalah:

1. Pengujian waktu pengisian dengan mini water pump

2. Pengujian penyajian minuman

3. Pengujian waktu penyajian minuman

4. Pengujian pengadukan minuman

Dengan dilakukan pengujian-pengujian ini diharapkan dapat diketahui performa dari alat yang sudah dibuat dengan lebih mendalam.

\section{HASIL PENELITIAN DAN PEMBAHASAN}

Setelah melewati proses perancangan dan pembuatan, hasil alat penyaji minuman tersebut dapat dilihat seperti pada Gambar 7 dan 8 . 
Jurnal ECOTIPE, Vol. 8, No.2, Oktober 2021, Hal. 112-119

p-ISSN 2355-5068, e-ISSN 2622-4852

Akreditasi Kemenristekdikti (SINTA 4), SK. No.10/E/KPT/2019

DOI: $10.33019 /$ jurnalecotipe.v8i2.2538

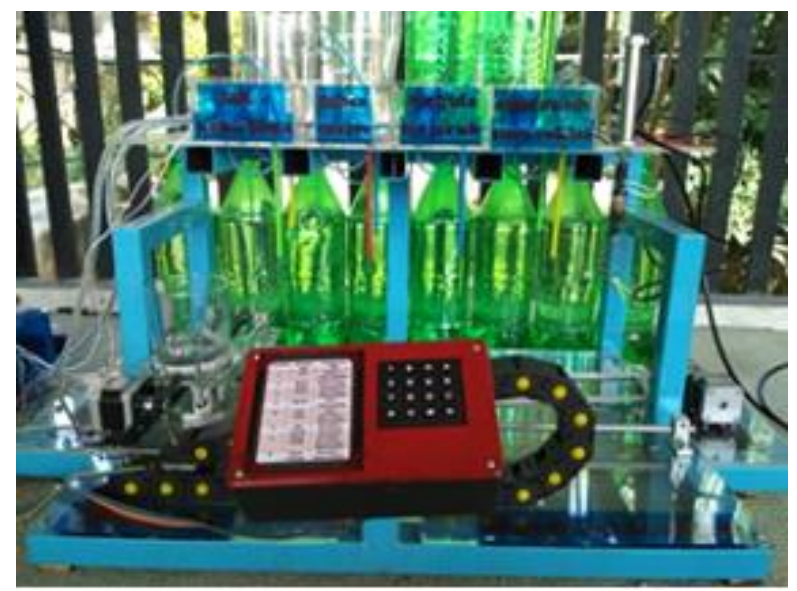

Gambar 7. Hasil implementasi robot

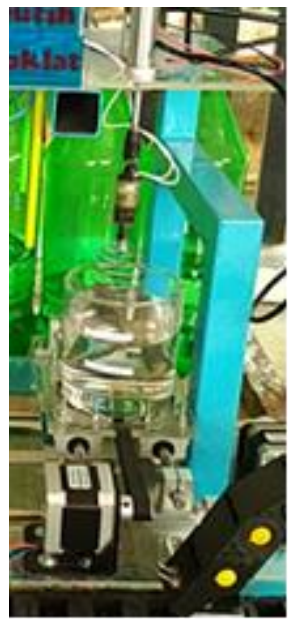

Gambar 8. Bagian pengaduk pada alat

Penggunaan mini water pump menjadi salah satu pembeda dengan penelitian-penelitian yang sudah dilakukan sebelumnya. Penggunaan mini water pump ini menyebabkan wadah minuman atau botol tidak perlu diletakkan secara terbalik lagi dan proses turunnya minuman tidak mengandalkan efek gravitasi lagi, dengan perubahan ini diharapkan campuran bahan minuman kan lebih presisi dan tidak dipengaruhi volume cairan pada wadah. Begitu juga dengan bagian pengaduk dimana pada penelitianpenelitian sebelumnya hal ini tidak ada sama sekali.

\section{A. Pengujian Waktu Pengisian dengan Mini Water Pump}

Adapun prosedur pengujian ini adalah dengan mengaktifkan pompa untuk melakukan pengisian dari wadah (botol) ke gelas sebanyak $100 \mathrm{ml}$. Pengujian ini dilakukan sebanyak 10 kali pada tiap-tiap pompa. Hasil pengujian ini dapat dilihat pada Tabel 1 dan selanjutnya hasil pengujian ini akan menjadi dasar perhitungan lama aktif pompa dalam proses pengisian minuman.

Tabel 1. Data lama proses pengisian tiap pompa

\begin{tabular}{|c|c|c|c|c|c|c|c|c|}
\hline \multirow{2}{*}{ Petcebaan } & \multicolumn{8}{|c|}{ 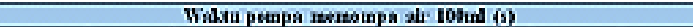 } \\
\hline & NGAOI & JeA 2 & Dlecers & DJeserd & Mhotors & MLotot6 & $\operatorname{sen} \theta$ & Notot8 \\
\hline 1 & 13,5 & 14 & 12,9 & 12,7 & $1 \leqslant, 3$ & 12,3 & 13,2 & 16,7 \\
\hline 2 & 13,8 & 13.8 & 12.5 & 124 & 11.5 & 12,6 & 14 & 16.9 \\
\hline 3 & 136 & $1: .2$ & 13.2 & 126 & 12.1 & 13.3 & 14.3 & 13.1 \\
\hline 4 & 14,0 & $1+0$ & 14,2 & 125 & 12,1 & 13,6 & 14,9 & 18,7 \\
\hline 5 & 15,1 & 146 & 143 & 135 & 11,6 & 13,7 & 14,6 & 18,3 \\
\hline 6 & 18,4 & 143 & 148 & 13,4 & 12.3 & 13.8 & 14 & 19.2 \\
\hline ; & 10,7 & 156 & 15,4 & 150 & 111.7 & 13.5 & 19,2 & 13.1 \\
\hline 8 & 14,6 & 15,3 & $15 \div 2$ & 13,9 & 12,5 & 12,9 & 14,3 & 19,3 \\
\hline 9 & $1 \leq S$ & $1 \leq 8$ & 162 & 14.1 & 12.3 & 14.7 & 13.9 & 18.5 \\
\hline 10 & 189 & 150 & 159 & $1 k 3$ & 11,5 & 14,7 & 15,4 & 18.7 \\
\hline Ratarain & 14,42 & 14,94 & 15,46 & 15,04 & 11,99 & 13,51 & 14,17 & 18,23 \\
\hline
\end{tabular}

Dari hasil pengujian ini diketahui bahwa untuk melakukan pengisian volume yang sama ternyata dibutuhkan waktu yang berbeda-beda, hal ini terjadi disebabkan oleh beberapa faktor yaitu: (1)posisi pompa, (2)kinerja tiap pompa yang tidak seragam. Data ini berikutnya menjadi panduan dalam pemrograman pencampuran bahan minuman sehingga lama aktifnya mini pump akan disesuaikan dengan volume yang inginkan.

\section{B. Pengujian Penyajian Minuman}

Pada pengujian ini akan diuji kemampuan robot dalam mengenali permintaan jenis minuman yang dilakukan user lewat penekanan keypad dan kemudian kemampuan robot untuk mengisi gelas sesuai bahanbahan minuman yang dikehendaki tadi oleh pengguna baik itu minuman yang sejenis ataupun jenis minuman campuran. Pengujian dilakukan sebanyak 5 kali untuk memastikan inputan keypad berfungsi, dan selanjutnya diamati pergerakan robot dan komposisi pengisian minuman sesuai dengan campuran yang telah ditentukan. Data hasil pengujian ini dapat dilihat pada Tabel 2.

Dari hasil pengujian ini dapat diketahui bahwa robot dapat mengenali jenis minuman yang dipesan baik itu minuman berbahan sejenis ataupun minuman campuran dan proses pengisian dilakukan dengan baik sesuai komposisi bahan minuman yang sudah ditentukan sebelumnya dengan tingkat keberhasilan $100 \%$. 
Jurnal ECOTIPE, Vol. 8, No.2, Oktober 2021, Hal. 112-119

p-ISSN 2355-5068, e-ISSN 2622-4852

Akreditasi Kemenristekdikti (SINTA 4), SK. No.10/E/KPT/2019

DOI: $10.33019 /$ jurnalecotipe.v8i2.2538

Tabel 2. Data pengujian penyajian minuman

\begin{tabular}{|c|c|c|c|c|c|}
\hline \multirow{2}{*}{ Pengujian Minuman } & \multicolumn{5}{|c|}{ Percobaan } \\
\cline { 2 - 6 } & $\mathbf{1}$ & $\mathbf{2}$ & $\mathbf{3}$ & $\mathbf{4}$ & $\mathbf{5}$ \\
\hline Teh & ok & ok & ok & ok & ok \\
\hline Kuku bima & ok & ok & ok & ok & ok \\
\hline Fanta & ok & ok & ok & ok & ok \\
\hline Sprite & ok & ok & ok & ok & ok \\
\hline Air gula & ok & ok & ok & ok & ok \\
\hline Air jeruk & ok & ok & ok & ok & ok \\
\hline Susu putih & ok & ok & ok & ok & ok \\
\hline Susu coklat & ok & ok & ok & ok & ok \\
\hline Fanta + susu putih & ok & ok & ok & ok & ok \\
\hline Kuku bima + susu putih & ok & ok & ok & ok & ok \\
\hline Air gula + susu putih & ok & ok & ok & ok & ok \\
\hline Teh + susu putih & ok & ok & ok & ok & ok \\
\hline Teh + air gula + susu putih & ok & ok & ok & ok & ok \\
\hline Air gula + air jeruk & ok & ok & ok & ok & ok \\
\hline Air gula + air jeruk + susu putih & ok & ok & ok & ok & ok \\
\hline Air gula + susu coklat & ok & ok & ok & ok & ok \\
\hline
\end{tabular}

\section{Pengujian Waktu Penyajian Minuman}

Pada pengujian ini akan diuji berapa lama waktu yang dibutuhkan robot untuk menyajikan minuman yang dipesan dengan volume yang sama $(200 \mathrm{ml})$. Proses penghitungan waktu dimulai sesaat setelah tombol keypad input jenis minuman ditekan sampai pada gelas kembali ke posisi awal tanda selesainya proses penyajian minuman. Hasil pengujian ini terbagi menjadi dua bagian dimana pada bagian pertama dikhususkan untuk minuman berbahan sejenis sedang bagian kedua dikhususkan untuk pengujian waktu penyajian jenis minuman campuran ( 2 atau 3 bahan campuran minuman). Hasil pengujian ini dapat dilihat pada Tabel 3 dan Tabel 4.

Tabel 3. Waktu penyajian minuman sejenis (satuan)

\begin{tabular}{|c|c|}
\hline Nama Minuman (satuan) & Waktu pergerakan minuman satuan \\
\hline Teh & 29.50 \\
\hline Kuku bima & 31.60 \\
\hline Fanta & 36.00 \\
\hline Sprite & 35.50 \\
\hline Air gula & 27.40 \\
\hline Air jeruk & 32.00 \\
\hline Susu putih & 32.40 \\
\hline Susu coklat & 41.90 \\
\hline
\end{tabular}

Tabel 4. Waktu penyajian minuman campuran

\begin{tabular}{|c|c|c|c|c|}
\hline \multirow{2}{*}{$\begin{array}{c}\text { Nama Minuman } \\
\text { (campuran) }\end{array}$} & \multicolumn{3}{|c|}{ Persentase } & \multirow{2}{*}{$\begin{array}{c}\text { Waktu Total } \\
\text { (detik) }\end{array}$} \\
\cline { 2 - 3 } & $\begin{array}{c}\text { Minuman } \\
\mathbf{x}\end{array}$ & $\begin{array}{c}\text { Minuman } \\
\mathbf{y}\end{array}$ & $\begin{array}{c}\text { Minuman } \\
\mathbf{z}\end{array}$ & \\
\hline Fanta + susu putih & $\mathrm{F}=70 \%$ & $\mathrm{Sp}=30 \%$ & - & 40.71 \\
\hline Kuku bima + susu putih & $\mathrm{Kb}=70 \%$ & $\mathrm{Sp}=30 \%$ & - & 38.80 \\
\hline Air gula + susu putih & $\mathrm{Ag}=20 \%$ & $\mathrm{Sp}=80 \%$ & - & 35.00 \\
\hline Teh + susu putih & $\mathrm{T}=70 \%$ & $\mathrm{Sp}=30 \%$ & - & 36.40 \\
\hline Teh + air gula + susu putih & $\mathrm{T}=50 \%$ & $\mathrm{Ag}=20 \%$ & $\mathrm{Sp}=30 \%$ & 36.30 \\
\hline Air gula + air jeruk & $\mathrm{Ag}=20 \%$ & $\mathrm{Aj}=80 \%$ & - & 36.00 \\
\hline Air gula + air jeruk + susu putih & $\mathrm{Ag}=20 \%$ & $\mathrm{Aj}=50 \%$ & $\mathrm{Sp}=30 \%$ & 37.30 \\
\hline Air gula + susu coklat & $\mathrm{Ag}=20 \%$ & $\mathrm{Sc}=80 \%$ & - & 42.90 \\
\hline
\end{tabular}

Dari dua hasil pengujian waktu penyajian minuman sejenis yang sudah dilakukan tersebut diketahui bahwa secara umum hasil pengujian menunjukkan hasil korelasi yang positif antara waktu yang dibutuhkan dengan jenis minuman. Mengingat posisi atau jarak wadah bahan minuman tersebut disusun secara berurutan sehingga dibutuhkan waktu yang lebih lama untuk menyajikan minuman yang paling bawah. Dari tren tersebut juga didapati bahwa ada penyimpangan pada waktu pengisian jenis minuman Fanta dan Sprite dimana posisi jarak kedua minuman tersebut lebih dekat dari pada air gula, air jeruk dan susu putih akan tetapi waktu yang dibutuhkan untuk mengisi kedua jenis minuman tersebut ternyata lebih lama (36 dan 35,5 detik).

Setelah ditelaah lebih lanjut, ternyata diketahui bahwa untuk cairan bersoda ternyata membutuhkan waktu yang lebih lama dalam proses pengisiannya. Hal serupa juga tercermin pada hasil pengujian waktu penyajian minuman campuran. Secara umum hasil pengujian waktu penyajian ini memberikan hasil yang positif mengingat waktu yang dibutuhkan untuk penyajian minuman pada robot ini dibawah rentang 1 menit. Hal ini menunjukkan bahwa pengguna tidak perlu menunggu lama untuk mendapatkan minumannya pada robot ini.

\section{Pengujian pengadukan minuman}

Pengujian pengadukan minuman dilakukan untuk mengetahui apakah mekanisme pengadukan dapat dilakukan dengan baik untuk jenis minuman yang bersifat campuran dari beberapa bahan minuman. Mekanisme pengadukan dikatakan berhasil jika proses pengadukan dilakukan yang ditandai dengan bekerjanya silinder pneumatic untuk menurunkan bagian pengaduk dan selanjutnya motor dc pemutar pengaduk juga aktif pada kurun waktu tertentu pada menu minuman yang sifatnya campuran.

Hasil pengujian pengadukan ini dapat dilihat pada Tabel 5 berikut ini.

Tabel 5. Hasil pengujian pengadukan minuman

\begin{tabular}{|c|c|c|c|c|c|}
\hline \multirow{2}{*}{ Pengadukan Minuman Campuran } & \multicolumn{5}{|c|}{ Percobaan } \\
\cline { 2 - 6 } & $\mathbf{1}$ & $\mathbf{2}$ & $\mathbf{3}$ & $\mathbf{4}$ & $\mathbf{5}$ \\
\hline Fanta + susu putih & ok & ok & ok & ok & ok \\
\hline Kuku bima + susu putih & ok & ok & ok & ok & ok \\
\hline Air gula + susu puth & ok & ok & ok & ok & ok \\
\hline Teh + susu putih & ok & ok & ok & ok & ok \\
\hline Teh + air gula + susu putih & ok & ok & ok & ok & ok \\
\hline Air gula + air jeruk & ok & ok & ok & ok & ok \\
\hline Air gula + air jeruk + susu putih & ok & ok & ok & ok & ok \\
\hline Air gula + susu coklat & ok & ok & ok & ok & ok \\
\hline
\end{tabular}

Setelah dilakukan 5 kali pengujian pengadukan untuk tiap-tiap campuran minuman diketahui bahwa mekanisme pendeteksian jenis minuman campuran dan proses pengadukannya dapat berkerja dengan baik dengan tingkat keberhasilan $100 \%$. 
Jurnal ECOTIPE, Vol. 8, No.2, Oktober 2021, Hal. 112-119

p-ISSN 2355-5068, e-ISSN 2622-4852

Akreditasi Kemenristekdikti (SINTA 4), SK. No.10/E/KPT/2019

DOI: 10.33019/jurnalecotipe.v8i2.2538

\section{KESIMPULAN}

Setelah melakukan pengujian dan menganalisa data yang didapat maka bebrapa hal yang dapat disimpulkan pada penelitian ini antara lain adalah:

1. Waktu yang dibutuhkan oleh pompa-pompa yang digunakan pada penelitian ini untuk mengisi cairan dengan volume $100 \mathrm{ml}$ berada pada rentang 11,9 detik sampai dengan 18,25 detik. Rentang yang cukup jauh ini dikarenakan oleh perbedaan posisi pompa dan yang paling utama adalah performa tiap-tiap pompa itu sendiri yang ternyata kurang seragam meskipun berasal dari 1 pabrikan.

2. Robot ini mampu menanggapi pesanan minuman yang dimasukkan pengguna melalui penekanan keypad dan kemudian mampu menyajikan pesanan minuman tersebut dengan benar dengan unjuk kerja keberhasilan $100 \%$.

3. Lamanya waktu yang dibutuhkan robot ini untuk menyajikan minuman dari 1 jenis bahan minuman saja berada pada rentang 27,4 detik (Air Gula) dan yang paling lama adalah Susu Coklat yang membutuhkan 41,9 detik. Rata-rata waktu penyajian untuk minuman berbahan sejenis ini adalah 33,28 detik.

4. Lama waktu penyajian untuk minuman campuran dari beberapa bahan berada pada rentang 35 detik (Air Gula + Susu Putih) dan 42,9 detik untuk Air Gula + Susu Coklat. Rata-rata waktu yang dibutuhkan untuk menyajikan minuman campuran adalah 37,9 detik.

5. Mekanisme pengadukan untuk minuman campuran dapat bekerja dengan baik dengan unjuk kerja keberhasilan sebesar $100 \%$.

Pengembangan ke depannya untuk robot ini dapat digunakan dan dikemas lebih baik lagi untuk produkproduk minuman seperti jamu sehingga dapat mengangkat warisan budaya dengan wajah teknologi yang lebih baik.

\section{REFERENSI}

[1] Siciliano B., Khatib O. Robotics and the Handbook. In: Siciliano B., Khatib O. (eds) Springer Handbook of Robotics. Springer Handbooks. Springer, 2016.

[2] Mary Ellen Foster, Simon Keizer, and Oliver Lemon. Towards action selection under uncertainty for a socially aware robot bartender, In Proceedings of the 2014 ACM/IEEE international conference on Human-robot interaction HRI '14. Association for Computing Machinery, New York, NY, USA, 2014, 158-159. DOI:https://doi.org/10.1145/2559636.2559805.

[3] Silvia Rossi, Elena Dell'Aquila, Gianpaolo Maggi, and Davide Russo. What Would You Like to Drink? Engagement and Interaction Styles in HRI. In Companion of the 2020 ACM/IEEE International Conference on Human-Robot Interaction HRI '20. Association for Computing Machinery, New York, NY, USA, 2020, 415-417. DOI:https://doi.org/10.1145/3371382.3378343.

[4] Cain, L. N., Thomas, J. H. and Alonso Jr., M., From sci-fi to sci-fact: the state of robotics and AI in the hospitality industry, Journal of Hospitality and Tourism Technology, Vol. 10 No. 4, 2019, pp. 624-650. https://doi.org/10.1108/JHTT-07-20180066.

[5] Foster Mary Ellen. Natural language generation for social robotics: opportunities and challenges, Phil. Trans. R. Soc. B3742018002720180027, 2019. http://doi.org/10.1098/rstb.2018.0027.

[6] H. Q. T. Ngo, T. P. Nguyen and H. Nguyen, Investigation on Barbot to Serve Human in Public Space, 2018 4th International Conference on Green Technology and Sustainable Development (GTSD), 2018, pp. 300-305, doi: 10.1109/GTSD.2018.8595543.

[7] Ivanov, S., Gretzel, U., Berezina, K., Sigala, M. and Webster, C. (2019), Progress on robotics in hospitality and tourism: a review of the literature, Journal of Hospitality and Tourism Technology, Vol. 10 No. 4, pp. 489-521. https://doi.org/10.1108/JHTT-08-2018-0087.

[8] Patrick Barron, C. S. E., C. S. E. Chris Wong, E. E. Ben Ivaldi, and C. S. E. John Fouad. Alfred: Wifi-Enabled Automated Mixed Drink Maker.

[9] The Inebriator, Dave Parrack, Mei 2021 available: https://newatlas.com/Inebriator-robotbartender/23974/

[10] Rybin, V.; Karimov, T.; Sigaeva, M.; Solomevich, E.; Kolev, G.; Kopets, E. Design of a Smart Bartender with Peristaltic Pumps. Inventions 2019, $4, \quad 26$. https://doi.org/10.3390/inventions4020026. 
Jurnal ECOTIPE, Vol. 8, No.2, Oktober 2021, Hal. 112-119

p-ISSN 2355-5068, e-ISSN 2622-4852

Akreditasi Kemenristekdikti (SINTA 4), SK. No.10/E/KPT/2019

DOI: 10.33019/jurnalecotipe.v8i2.2538

[11] Wright, Michael. How to Control Stepper

Motors: The Most Comprehensive, Easy-to-

understand Advanced Guide for Hobbyists and

Experts. United States: CreateSpace Independent

Publishing Platform, 2016.

[12] Udayashankara, V. Microcontroller. India,

McGraw-Hill Education (India) Pvt

Limited, 2009. 